\title{
JNTIP
}

\section{PENGARUH PEMBERIAN RASIO RUMPUT ODOT (Pennisetum purpureum cv. Matt) DAN KALIANDRA (Calliandra calothyrsus) PADA SAAT KEMARAU TERHADAP TINGKAT STRES DOMBA DI BPPTDK MARGAWATI GARUT}

\section{The Effect of Combination Between Odot (Pennisetum Purpureum Cv. Matt) Grass and Kaliandra (Calliandra Calothyrsus) at Dry Season on Stress Level of Sheep In BPPTDK Margawati Garut}

\author{
Salsabilla Nazhari ${ }^{1}$, Kurnia A. Kamil ${ }^{2}$, Ronnie Permana ${ }^{2}$
}

${ }^{1}$ Program Sarjana Ilmu Peternakan, Fakultas Peternakan, Universitas Padjadjaran Kampus Jatinagor, Jl. Raya Bandung-Sumedang KM.21, Jatinangor-Sumedang, Jawa Barat 45363

${ }^{2}$ Laboratorium Fisiologi Ternak dan Biokimia, Departemen Nutrisi Ternak dan Teknologi

Ternak Pakan, Fakultas Peternakan, Universitas Padjadjaran, Bandung Kampus Jatinangor, J1. Raya Bandung-Sumedang KM.21, Jatinangor-Sumedang, Jawa Barat 45363

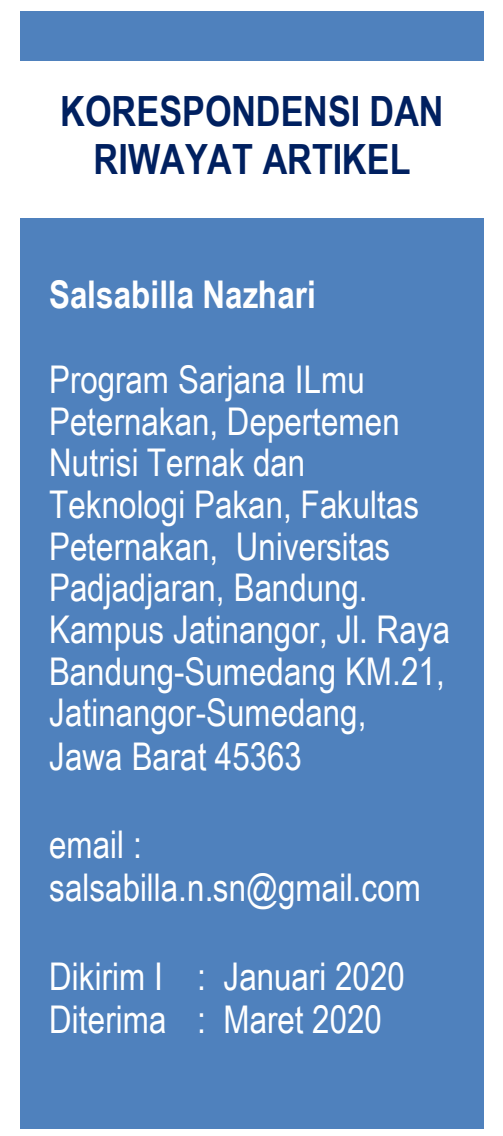

\begin{abstract}
ABSTRAK
Penelitian bertujuan untuk mengetahui pengaruh pemberian rasio rumput Odot (Pennisetum purpureum cv. Mott) dan Kaliandra (Calliandra calothyrsus) pada saat kemarau terhadap tingkat stres Domba Garut. Penelitian ini dilaksanakan di BPPTDK Margawati Garut dan Analisis darah di Multitest Lab, Bandung pada tanggal 2 Januari 2020 sampai 16 Januari 2020. yang Objek dalam penelitian ini adalah 25 ekor Domba Garut dengan bobot badan 20-40 kg yang diambil secara acak. Metode yang digunakan dalam penelitian ini ialah eksperimental dengan Rancangan Acak Lengkap (RAL) dengan lima perlakuan yang diulang sebanyak lima kali. Perlakuan berupa $\mathrm{P} 0=$ Tanpa perlakuan, $\mathrm{P} 1=100 \%$ Rumput Gajah, P2 $=75 \%$ Rumput Gajah $+25 \%$ Calliandra calothyrsus, $\mathrm{P} 3=50 \%$ Rumput Gajah $+50 \%$ Calliandra calothyrsus, dan P4= 25\% Rumput Gajah $+75 \%$ Calliandra calothyrsus. Data analisis dengan uji sidik ragam. Hasil penelitian menunjukkan bahwa pemberian rasio Rrumput Oodot dan Kka liandra berpengaruh tidak nyata $(\mathrm{P}>0,05)$ jumlah neutrofil, jumlah limfosit, maupun rasio neutrophil dan limfosit pada Domba Garut, namun ternyata domba-domba di BPPTDK Margawati Garut mengalami rendahnya jumlah neutrofil (neutropenia).
\end{abstract}

Kata kunci: rumput gajah mini (odot), kaliandra, rasio N/L, domba Garut 


\section{ABSTRACT}

The research aims to determine the effect of combination between Odot (Pennisetum purpureum cv. Matt) grass and Kaliandra (Calliandra calothyrsus) at dry season on stress level of sheep in BPPTDK Margawati Garut. This research was held in BPPTDK Margawati Garut on January 2020 and the samples was tested in Multitest Lab, Bandung. The material used 25 Garut sheeps with a body weight of 20-40 kg with coefficient variation 8,65\%. The experimental method used a Completely Randomized Design (CRD) with five treatments and five times repitition. The treatments were $P 0=$ without treatment, $P 1=100 \%$ Odot Grass, $P 2=75 \%$ Odot Grass $+25 \%$ Calliandra calothyrsus, $P 3=50 \%$ Odot Grass $+50 \%$ Calliandra calothyrsus, dan P4 $=25 \%$ Odot Grass $+75 \%$ Calliandra calothyrsus. Data were analysed with analysis of variance. The results showed that the use Odot grass and Kaliandra until $75 \%$ had no effect $(P>0,05)$ on neutrophil and limfosit value as well as $N / L$ ratio of sheep. However, it was found that the sheeps in BPPTDK Margawati Garut had neutropenia.

Keywords: odot grass, kaliandra, N/L ratio, Garut sheep

\section{PENDAHULUAN}

Domba Garut merupakan salah satu plasma nutfah yang dimiliki Jawa Barat yang perlu dilestarikan dan dikembangkan. Domba Garut adalah rumpun domba asli dari Jawa Barat, dengan ciri khas memiliki kuping rumpung $(<4 \mathrm{~cm})$ atau ngadaun hiris $(4-8$ $\mathrm{cm})$ dengan ekor ngabuntut beurit atau ngabuntut bagong (Heriyadi, 2001).

Produktivitas ternak dipengaruhi oleh berbagai faktor yaitu, genetik, pakan, dan manajemen. Pakan merupakan faktor penting dalam usaha peternakan. Setiap perusahaan ternak memanfaatkan rumput sebagai pakan utama pada ternaknya, sedangkan dalam satu tahun siklus produksi tidak semua rumput dan konsentrat tersedia untuk mencukupi kebutuhan pakan ternak, terutama pada musim kemarau. Hal tersebut mengakibatkan seringkali perusahaan memanfaatkan jerami atau silase sebagai bahan pakan, yang bahkan belum tentu dapat mencukupi juga.

Rumput gajah mini (Pennisetum purpureum cv. Mott) merupakan jenis rumput unggul yang mempunyai produktivitas dan kandungan zat gizi yang cukup tinggi serta memiliki palatabilitas yang tinggi bagi ternak ruminansia (Syarifuddin, 2006; Santosa dkk., 2012). Respon ternak domba terhadap rumput gajah cukup tinggi, baik konsumsi bahan kering maupun daya cerna bahan organik maupun serat kasar. Disamping itu, terdapat hijauan lain seperti leguminosa yang sangat potensial untuk dimanfaatkan sebagai pakan ternak karena mengandung PK sebesar 20-25\% (Willyan dkk., 2007).

Pemberian leguminosa pada ruminansia harus dibatasi karena di dalam leguminosa terdapat zat antinutrisi, salah satunya yaitu tannin sebesar $11 \%$ (Tangendjadja dan Wina, 2000; Adawiah dkk., 2007; Tanuwiria, 2004,2007a,b)). Pemberian leguminosa dengan jumlah tannin yang tinggi akan mengakibatkan ternak keracunan, namun tannin dapat memberikan pengaruh positif apabila pemberiannya masih dalam batas tertentu.

Kaliandra (Calliandra calothyrsus) adalah leguminosa yang banyak dimanfaatkan sebagai pengendali erosi dan tanaman naungan. Kandungan nutrisi daun kaliandra cukup potensial sebagai pakan, terutama sebagai pakan sumber protein yaitu mengandung 20-25 persen (Willyan dkk., 2007; Tanuwiria dkk., 2007), sehingga dapat menjadi alternatif sebagai pengganti konsentrat. Faktor pembatas pemanfaatannya adalah tannin.

Tanin dikenal sebagai senyawa antinutrisi karena kemampuannya membentuk ikatan komplek dengan protein. Kemampuan tanin untuk mengendapkan protein ini disebabkan tanin memiliki sejumlah group fungsional yang dapat membentuk komplek kuat dengan molekul- 
molekul protein (Mutaqin dkk., 2019; Susilawati dkk., 2019; Mushawwir dkk., 2020a,b; Tanuwiria dkk., 2020), oleh karena itu secara umum tanin dianggap sebagai antinutrisi yang merugikan (Makkar, 1993).

Produktivitas ternak yang tinggi, salah satunya ditunjukkan oleh status atau kondisi fisiologi yang baik. Respon pertahanan tubuh terhadap penyakit yang dilakukan oleh sel darah putih merupakan salah satu indikator penentu kondisi fisiologi ternak. Penghitungan indeks stres dilakukan dengan menggunakan perbandingan neutrofil dengan limfosit (N/L) (Kannan dkk., 2000).

Berdasarkan uraian tersebut maka penulis tertarik untuk melakukan penelitian mengenai tingkat stres domba yang dilihat dari rasio neturofil dan limfosit ternak itu sendiri dengan pemberian kombinasi rasio rumput odot dan leguminosa.

\section{BAHAN DAN METODE PENELITIAN}

\section{Ternak Percobaan}

Hewan percobaan yang digunakan dalam penelitian adalah 25 ekor Domba Garut jantan kisaran umur 1 sampai 2 tahun dengan bobot badan sekitar 20-40 kg. Sistem pemeliharaan pada ternak percobaan dilakukan secara acak yang masing-masing dipelihara dalam kandang individu.

\section{Ransum Percobaan}

Leguminosa pohon yang terdiri atas kaliandra diperoleh dari kebun rumput milik Unit Pelaksana Teknis Dinas - Balai
Margawati, Garut. Adapun kandungan nutrien bahan pakan penelitian terdapat pada Tabel 1.

\section{Alat dan Bahan Penelitian}

Peralatan dan bahan yang digunakan untuk melakukan penelitian ini adalah sebagai berikut:

1. Kandang individu, digunakan untuk tempat pemeliharaan ternak.

2. Timbangan kapasitas 100 kilogram, digunakan untuk menimbang domba.

3. Timbangan digital kapasitas 10 kilogram, digunakan untuk menimbang masing masing bahan pakan yang diberikan.

4. Tempat Pakan, digunakan untuk tempat menampung bahan pakan.

5. Seperangkat Alat Tulis, berupa pulpen dan buku catatan yang digunakan untuk mencatat data yang telah diperoleh saat penelitian.

6. Automatic hematology analyzer, digunakan untuk menghitung analisa jumlah sel darah.

7. Cooling box, digunakan untuk menyimpan tabung EDTA yang berisi darah domba

8. Sarung tangan, digunakan untuk menjaga kebersihan saat pengambilan sampel darah.

9. Spuit, digunakan untuk pengambilan sampel darah ternak.

10. Tabung EDTA ber-heparin,

Tabel 1. Kandungan Nutrien Bahan Pakan Penelitian

\begin{tabular}{cccccccc}
\hline No & Hijauan & BK & PK & LK & SK & Abu & Tanin \\
\hline 1 & & Calliandra $^{1}$ & & 29,28 & 5,55 & 9,44 & \\
\hline 2 & R. Gajah Mini ${ }^{1}$ & 13,55 & 13,94 & & & $11,00^{3}$ \\
\hline
\end{tabular}

Sumber : ${ }^{1)}$ Sirait, dkk (2014), ${ }^{2)}$ Novia, dkk (2015); ${ }^{3)}$ Tangendjaja, dkk (1992)

Perbibitan Pengembangan Ternak Domba dan Kambing (UPTD BPBPTDK) digunakan untuk menyimpan darah ternak yang sudah diambil. 


\section{METODE PENELITIAN}

\section{Tahap Persiapan Penilitian}

a. Menyiapkan domba Garut jantan yang memiliki bobot badan $\pm 20-40$ kilogram sebanyak 25 ekor. Masingmasing domba dikandangkan dalam kandang individu.

b. Menyiapkan tempat pakan dan tempat minum pada masing-masing kandang.

\section{Tahap Penelitian}

Calliandra calothyrsus yang digunakan sebagai pakan utama diperoleh dari kebun percobaan yang dipotong pada umur tanam berkisar sekitar 45 hari. Calliandra calothyrsus diberikan setelah dilayukan, yang dicampur dengan rumput odot, jumlah pakan disesuaikan dengan kebutuhan $10 \%$ dari bobot hidup. Pakan diberikan tiga kali dalam sehari yaitu pada pagi (08:00), siang (12.00), dan sore hari (16:00). Ternak dibiarkan beradaptasi terhadap pakan selama 7 hari.

\section{Pengambilan sampel darah}

a. Mengambil sampel darah domba dari vena jugularis

b. Membersihkan sekitar pembuluh darah menggunakan kapas yang dibasahi dengan alkohol guna untuk mengetahui pembuluh darah lebih jelas

c. Memasukkan spuit pada vena jugularis tersebut

d. Menarik jarum suntik secara perlahan

e. Mengambilan darah pada masing - masing domba

f. Memasukkan darah ke dalam tabung EDTA

g. Memasukkan tabung EDTA ke dalam cooling box

h. Membawa sampel darah ke Lab. Multitest, Bandung untuk dilakukan pemeriksaan jumlah neutrofil dan limfosit.

\section{Peubah yang Diamati}

\section{Jumlah Neutrofil}

Jumlah neutrofil dihitung dengan alat mikroskop, dengan menggunakan pipet berbatu putih. Prinsip ini adalah menghitung jumlah neutrophil dari darah pada gelas objek yang telah dikeringkan dan diwarnai dengan giemsa yang berfungsi sebagai pewarna neutrofil.

\section{Jumlah Limfosit}

Jumlah limfosit dihitung dengan alat mikroskop, dengan menggunakan pipet berbatu putih. Prinsip ini adalah menghitung jumlah neutrophil dari darah pada gelas objek yang telah dikeringkan dan diwarnai dengan giemsa yang berfungsi sebagai pewarna limfosit.

\section{Rasio Neutrofil dan Limfosit}

Rasio neutrofil dan limfosit berdasarkan perbandingan antara jumlah neutrofil dan limfosit, selain itu yang harus diperhatikan adalah konsistensi data pada semua ulangan, bukan hanya rata-rata.

\section{Rancangan Percobaan dan Analisis Statistik}

Rancangan yang digunakan pada penelitian ini adalah rancangan acak lengkap (RAL) dengan lima perlakuan dan masingmasing perlakuan terdiri atas lima ulangan, dengan perlakuan sebagai berikut :

$\mathrm{R} 0=$ Tanpa perlakuan (Hijauan + Konsentrat) $\mathrm{R} 1=100 \%$ Rumput Gajah

$\mathrm{R} 2=75 \%$ Rumput Gajah $+25 \%$ Calliandra calothyrsus

$\mathrm{R} 3=50 \%$ Rumput Gajah $+50 \%$ Calliandra calothyrsus

$\mathrm{R} 4=25 \%$ Rumput Gajah $+75 \%$ Calliandra calothyrsus 
HASIL DAN PEMBAHASAN

\section{Pengaruh Perlakuan terhadap Jumlah Neutrofil}

Rata-rata jumlah neutrofil pada domba yang diberi perlakuan pemberian rasio rumput Odot dan Kaliandra disajikan pada Tabel 2.
(Lakshman, 2001). Penyebab dari kondisi ini belum diketahui dengan pasti dan memerlukan penelitian lebih lanjut untuk mengetahui penyebab rendahnya neutrofil (neutrophenia) pada domba Garut di BPPTDK Margawati Garut, namun untuk perkiraan sementara, dapat dikatakan kemungkinan penyebab rendahnya jumlah neutrofil (neutrophenia) diantaranya adalah

Tabel 2. Rata-rata Jumlah Neutrofil Domba Garut

\begin{tabular}{cccccc}
\hline & \multicolumn{5}{c}{ Perlakuan } \\
\cline { 2 - 6 } Ulangan & $\mathbf{R 0}$ & $\mathbf{R 1}$ & $\mathbf{R 2}$ & $\mathbf{R 3}$ & $\mathbf{R 4}$ \\
& $\ldots \ldots \ldots \ldots \ldots \ldots \ldots \ldots \ldots \ldots \ldots \ldots \ldots \ldots \ldots \ldots \ldots \ldots \ldots \ldots \ldots \ldots \ldots \ldots \ldots \ldots \ldots \ldots \ldots \ldots \ldots \ldots$ & $\mathbf{\%}$ \\
\hline $\mathbf{1}$ & 3.00 & 4.00 & 5.00 & 3.00 & 3.00 \\
$\mathbf{2}$ & 3.00 & 2.00 & 5.00 & 3.00 & 3.00 \\
$\mathbf{3}$ & 3.00 & 2.00 & 2.00 & 2.00 & 2.00 \\
$\mathbf{4}$ & 6.00 & 3.00 & 3.00 & 3.00 & 4.00 \\
$\mathbf{5}$ & 4.00 & 2.00 & 1.00 & 3.00 & 3.00 \\
\hline Jumlah & 19.00 & 13.00 & 16.00 & 14.00 & 15.00 \\
\hline Rataan & 3.80 & 2.60 & 3.20 & 2.80 & 3.00 \\
\hline STDV & 1.30 & 0.89 & 1.78 & 0.44 & 0.70 \\
\hline
\end{tabular}

Keterangan: Analisis Lab. Multitest Bandung, 2020

$\mathrm{R} 0=$ Tanpa perlakuan (Hijauan + Konsentrat)

$\mathrm{R} 1=100 \%$ Rumput Gajah

$\mathrm{R} 2=75 \%$ Rumput Gajah $+25 \%$ Calliandra calothyrsus

$\mathrm{R} 3=50 \%$ Rumput Gajah $+50 \%$ Calliandra calothyrsus

$\mathrm{R} 4=25 \%$ Rumput Gajah $+75 \%$ Calliandra calothyrsus

Berdasarkan Tabel 2, dapat dilihat bahwa rataan jumlah neutrofil pada Domba Garut selama penelitian berkisar antara 2,6\% sampai $3,8 \%$ dengan rata-rata jumlah neutrofil dari yang terkecil adalah pada perlakuan $\mathrm{R}_{1}$ sebesar 2,6\%, $\mathrm{R}_{3}$ sebesar 2,8\%, $\mathrm{R}_{4}$ sebesar $3 \%, \mathrm{R}_{2}$ sebesar $3,2 \%$, dan $\mathrm{R}_{0}$ atau kontrol sebesar $3,8 \%$.

Guna mengetahui pengaruh perlakuan terhadap jumlah neutrofil dilakukan analisis statistik. Hasil sidik ragam menunjukkan bahwa pengaruh perlakuan terhadap jumlah neutrofil menurun namun tidak berpengaruh nyata $(\mathrm{P}>0,05)$ dari kelompok kontrol. Jumlah neutrofil pada seluruh perlakuan berada jauh di bawah batas kisaran normal menurut Smith dan Mangkoewidjodjo (1998) yaitu antara $17,5-50 \%$.

Penurunan jumlah neutrofil dari jumlah normal dapat disebut neutropenia kondisi lingkungan seperti perubahan iklim yang drastis dan berkurangnya pembentukan neutrofil di sumsum tulang.

Pembentukan neutrofil di sumsum tulang yang terganggu bisa diakibatkan karena kekurangan $\mathrm{Cu}$. Kekurangan $\mathrm{Cu}$ dalam penelitian ini dapat disebabkan oleh $\mathrm{Fe}$ yang tinggi, yang kemungkinan dapat disebabkan oleh tanah tempat pakan ditanami, kandungan pada pakan hijauan yang diberikan, dan air minum yang dikonsumsi oleh ternak, hal ini sesuai dengan penelitian Nuraeni (2009) yang dalam penelitiannya didapatkan hasil ternak penelitian mengalami neutropenia yang diakibatkan oleh tingginya kadar zat besi pada perlakuan penelitian sehingga mengakibatkan defisiensi $\mathrm{Cu}$. Zat besi yang merupakan mineral yang bersifat antagonis dengan tembaga, akan menyebabkan 
penyerapan $\mathrm{Cu}$ terganggu (Perssonwaller, 2000; Mushawwir dkk., 2010, 2011). Pada level tertentu $\mathrm{Fe}$ menjadi racun sehingga menekan Cu (NRC, 1980). Defisiensi Cu dapat mengurangi pengaruh antibakterial dan pertahanan kekebalan (Perssonwaller, 2000; Mushawwir, 2015; Mushawwir dkk., 2017, 2018). Akibatnya fungsi $\mathrm{Cu}$ dalam sistem kekebalan tubuh, terutama produksi neutrofil menjadi terganggu.

\section{Pengaruh Perlakuan terhadap Jumlah Limfosit}

Rata-rata jumlah limfosit pada domba yang diberi perlakuan pemberian rasio rumput odot dan kaliandra disajikan pada Tabel 3.

Berdasarkan Tabel 3, dapat dilihat bahwa rataan jumlah limfosit pada domba Garut selama penelitian berkisar antara $86,2 \%$ sampai $91,4 \%$ dengan rata-rata jumlah limfosit dari yang terkecil adalah pada perlakuan $\mathrm{R}_{0}$ atau kontrol sebesar $86,2 \%, \mathrm{R}_{4}$ sebesar $89 \%, \mathrm{R}_{2}$ sebesar $89,2 \%, \mathrm{R}_{3}$ sebesar $90 \%$, dan $\mathrm{R}_{1}$ sebesar 91,4\%. Guna batas atas kisaran normal menurut Smith dan Mangkoewidjodjo (1998) yaitu antara 50$75 \%$.

Jumlah limfosit pada seluruh perlakuan berada pada batas atas normal, hal ini dikarenakan kekurangan $\mathrm{Cu}$ pada air minum akan mengakibatkan peningkatan produksi limfosit. Kekurangan $\mathrm{Cu}$ dapat berakibat pada respon pertumbuhan limfosit terhadap stimulasi mitogen (Arthington dkk., 1996 dalam McDowell, 2005). Sel-sel limfosit mempunyai fungsi yang sangat penting dalam mekanisme pertahanan atau imunitas spesifik terhadap benda asing. Limfosit adalah sel yang menghasilkan antibodi terhadap berbagai benda senyawa asing.

\section{Pengaruh Perlakuan terhadap Rasio Neutrofil dan Limfosit}

Penghitungan indeks stres dilakukan dengan menggunakan perbandingan neutrofil dengan limfosit (N/L) (Kannan dkk., 2000; Adriani dkk., 2014; Mushawwir dkk., 2019a,b). Berdasarkan Tabel 4. dapat dilihat bahwa rasio neutrofil dan limfosit pada berbagai perlakuan cukup bervariasi.

Tabel 3. Rata-rata Jumlah Limfosit Domba Garut

\begin{tabular}{|c|c|c|c|c|c|}
\hline \multirow[b]{2}{*}{ Ulangan } & \multicolumn{4}{|c|}{ Perlakuan } & \multirow[b]{2}{*}{$\mathbf{R 4}$} \\
\hline & $\mathbf{R 0}$ & $\mathbf{R 1}$ & $\mathbf{R 2}$ & $\mathbf{R 3}$ & \\
\hline & \multicolumn{5}{|c|}{ (1) } \\
\hline 1 & 90.00 & 91.00 & 87.00 & 88.00 & 90.00 \\
\hline 2 & 88.00 & 92.00 & 84.00 & 90.00 & 90.00 \\
\hline 3 & 88.00 & 92.00 & 91.00 & 92.00 & 91.00 \\
\hline 4 & 81.00 & 92.00 & 90.00 & 90.00 & 88.00 \\
\hline 5 & 84.00 & 90.00 & 94.00 & 90.00 & 86.00 \\
\hline Jumlah & 431.00 & 457.00 & 446.00 & 450.00 & 445.00 \\
\hline Rataan & 86.20 & 91.40 & 89.20 & 90.00 & 89.00 \\
\hline STD & 3.6331 & 0.8944 & 3.8340 & 1.4142 & 2 \\
\hline
\end{tabular}

Keterangan: Analisis Lab. Multitest Bandung, 2020

mengetahui pengaruh perlakuan terhadap jumlah limfosit dilakukan analisis statistik. Hasil sidik ragam menunjukkan bahwa pengaruh perlakuan terhadap jumlah limfosit tidak berpengaruh nyata $(\mathrm{P}>0,05)$. Jumlah limfosit pada seluruh perlakuan berada pada
Guna mengetahui pengaruh perlakuan terhadap rasio neutrofil dan limfosit telah dilakukan dilakukan analisis statistika. Hasil sidik ragam menunjukkan bahwa pengaruh perlakuan terhadap rasio neutrofil dan limfosit tidak berpengaruh nyata $(P>0,05)$, 
namun didapatkan bahwa jumlah neutrofil pada domba penelitian jauh di bawah batas normal dan jumlah limfosit pada domba penelitian jauh di atas batas normal. rasio neutrofil dan limfositnya jauh di bawah batas normal, bahkan mengalami neutropenia.

Didapatkan fakta juga bahwa

Tabel 4. Rataan Jumlah Sel Neutrofil, Limfosit, dan Rasio Neutrofil dan Limfosit

\begin{tabular}{cccc}
\hline \multirow{2}{*}{ Perlakuan } & \multicolumn{3}{c}{ Parameter } \\
\cline { 2 - 4 } & Neutrophil(\%) & Limfosit $(\%)$ & N/L \\
\hline P0 & 3,8 & 86,2 & 0,04 \\
P1 & 2,6 & 91,4 & 0,03 \\
P2 & 3,2 & 89,2 & 0,04 \\
P3 & 2,8 & 90,0 & 0,03 \\
P4 & 3,0 & 89,0 & 0,03 \\
\hline
\end{tabular}

Keterangan: Analisis Lab. Multitest Bandung, 2020

Berdasarkan Tabel 4, dapat dilihat bahwa rataan rasio neutrofil dan limfosit pada Domba Garut selama penelitian berkisar antara $0,03 \%$ sampai $0,04 \%$. Menurut Kannan dkk (2000) dan Mushawwir dkk., (2019c,d), indeks stres pada kambing normalnya bernilai 1,5 . Jika melebihi nilai 1,5 maka hewan tersebut diduga mengalami stres atau cekaman. Hal tersebut dapat dikatakan bahwa domba pada penelitian ini mengalami stres atau cekaman karena rataan pemberian rasio rumput Odot dan legum Kaliandra sampai $75 \%$ tidak mengakibatkan kematian pada ternak apabila diberikan dalam keadaan darurat atau waktu yang singkat. Dan apabila dilihat dari tingkah lakunya, ternak juga tidak terlihat lemas atau mengalami mencret. Berdasarkan Tabel 5. dapat dilihat pengaruh pemberian Kaliandra sampai sebanyak $75 \%$ terhadap konsumsi pakan pada ternak penelitian.

Tabel 5. Pengaruh Pemberian Perlakuan terhadap Konsumsi Pakan pada Domba Garut

\begin{tabular}{|c|c|c|c|c|c|}
\hline Perlakuan & $\begin{array}{c}\text { Pakan yang } \\
\text { diberikan } \\
\text {......... }\end{array}$ & $\begin{array}{l}\text { Sisa Pakan } \\
\ldots \ldots \ldots\end{array}$ & Perlakuan & $\begin{array}{c}\begin{array}{c}\text { Pakan yang } \\
\text { diberikan }\end{array} \\
\ldots \ldots \ldots k\end{array}$ & $\begin{array}{l}\text { Sisa Pakan } \\
\ldots . \ldots \ldots\end{array}$ \\
\hline P1R1 & 2,565 & Habis & P3R1 & 2,575 & Habis \\
\hline P1R2 & 2,505 & Habis & P3R2 & 3,220 & Habis \\
\hline P1R3 & 2,530 & Habis & P3R3 & 2,925 & Habis \\
\hline P1R4 & 2,745 & Habis & P3R4 & 2,700 & Habis \\
\hline P1R5 & 2,001 & Habis & P3R5 & 2,460 & Habis \\
\hline P2R1 & 2,835 & Habis & P4R1 & 3,930 & Habis \\
\hline $\mathrm{P} 2 \mathrm{R} 2$ & 2,150 & Habis & P4R2 & 3,500 & Habis \\
\hline P2R3 & 3,350 & Habis & P4R3 & 4,060 & Habis \\
\hline $\mathrm{P} 2 \mathrm{R} 4$ & 3,050 & Habis & P4R4 & 4,015 & Habis \\
\hline P2R5 & 2,575 & Habis & P4R5 & 2,860 & Habis \\
\hline
\end{tabular}

Keterangan: Analisis Lab. Multitest Bandung, 2020 
Berdasarkan Tabel 5, dapat dilihat bahwa ternak tidak mengalami penurunan konsumsi pada pakannya. Apabila ditinjau dari tingkah laku ternak terhadap tingkat racun dalam pakan, ternyata ternak juga memiliki kemampuan melakukan cyclic consumption, yaitu ternak mampu mengurangi efek dari racun dengan membatasi konsumsinya, baik secara langsung ketika dia pertama kali mengkonsumsi atau sampai efek keracunan tadi memberikan efek timbal balik yang negatif (Lopez, 2009, Adriani dkk., 2008, 2018; Mushawwir dkk., 2019a,b). Berdasarkan hal tersebut dapat dikatakan bahwa pemberian Kaliandra $75 \% \quad(8,25 \%$ tannin) tidak memberikan efek racun pada ternak karena ternak tidak membatasi konsumsi pada pakannya.

\section{KESIMPULAN}

Berdasarkan hasil penelitian dapat disimpulkan bahwa pemberian leguminosa Kaliandra sampai $75 \%$ dalam pakan domba Garut tidak menyebabkan perubahan tingkah laku yang negatif pada ternak seperti tandatanda lemas dan diare, bahkan tidak menyebabkan kematian sehingga dapat disimpulkan bahwa pemberian leguminosa Kaliandra sebesar sampai $75 \%$ aman digunakan selama pemberiannya dilakukan dalam keadaan darurat yaitu waktu yang sangat singkat (2 minggu).

Ternak mengalami stress akut karena rasio N/L yang jauh di bawah batas normal dan mengalami penurunan nilai neutrofil dari batas normal (neutropenia), akan tetapi ternak tidak mengalami keracunan bahkan penurunan konsumsi pakan.

\section{UCAPAN TERIMA KASIH}

Ucapan terima kasih disampaikan kepada seluruh pihak yang telah membantu penelitian ini, hingga penulisan artikel ini telah dilaksanakan dengan kontribusi yang sama dengan seluruh tim yang terlibat seperti yang tercantum sebagai penulis dalam artikel ini.

\section{DAFTAR PUSTAKA}

Adawiah, A., T. Sutardi, T. Toharmat, W. Manalu, N. Ramli, dan U.H. Tanuwiria. 2007. Respons terhadap suplementasi sabun mineral dan mineral organik serta kacang kedelai sangrai pada indikator fermentabilitas ransum dalam rumen domba. Media Peternakan. 30:162-169.

Adriani, L. dan A. Mushawwir. 2008. Kadar Glukosa Darah, Laktosa Dan Produksi Susu Sapi Perah Pada Berbagai Tingkat Suplementasi Mineral Makro. Fakultas Peternakan Universitas Padjadjaran.

Adriani, L., A. Mushawwir, B.R. Anastasia, and B. Rahayu. 2018. Effect of combination chitosan and turmeric powder (curcuma domestica val.) For improving blood lipid profile in broilers. Scientific Papers. Series D. Animal Science. LXI:225-229.

Adriani, L., A. Rochana. A.A. Yulianti, A. Mushawwir, and N. Indrayani. 2014. Profil serum glutamate oxaloacetat transaminase (SGOT) and glutamate pyruvate transaminase (SGPT) level of broiler that was given noni juice (Morinda citrifolia) and palm sugar (Arenga piata). Lucrări Ştiinţifice Seria Zootehnie. 62:101-105.

Ali, A. S. 2013. Jumlah Eritrosit, Kadar Hemoglobin dan Hematokrit Pada Berbagai Jenis Itik Lokal Terhadap Penambahan Probiotik Dalam Ransum. J. Ilmiah Peternakan. 1: 10011013.

Gartenberg, P.K., Mcdowell, L. R., Rodriguez, D., Wilkiinson, N., Conrat, J. H., and Martin, F. G. 1990. Evalution of trace mineral status of ruminants in northeast Mexico. Livestock Res. Rural Dev. 3:1-6

Guyton, A. C., dan Hall, J. E. 2007. Buku Ajar Fisiologi Kedokteran. Edisi 11. Cetakan I. Terjemahan Irawan S, K. A. Tragedi, dan A. Santos. 1997: EGC. Jakarta 
Hartoyo, B., Suhermiyati, S., Iriyanti, N., dan Susanti, E. 2015. performan dan profil hematologis darah ayam broiler dengan suplementasi herbal (fermenherfit). Prosiding Seminar Nasional Teknologi dan Agribisnis Peternakan (Seri III). Fakultas Peternakan Universitas Jendral Soedirman. Purwokerto

Heriyadi, D. 2012. Pernak-Pernik dan Senarai Domba Garut. Unpad Press. Bandung.

Hernawan, E., L. Adriani, U.H. Tanuwiria. 2015. Dry matter digestibility, VFA and $\mathrm{NH}_{3}$ production in vitro of sheep rations supplemented sweet orange waste. Scientific Papers-Animal Science Series: Lucrări Ştiinţifice Seria Zootehnie. 63:81-86.

Kannan, G. T., Terril, H., Kouakou, B., Gazal, O. S., Gelaye, S., Amoah, E. A., and Samake, S. 2000. Transportation of goats: effects on physiological stress responses and live weight loss. J. of Animal Science 2000. 78:1450-1457.

Lakshman, R. F. A. 2001. Neutrophil disorders and their management. J. of Clinical Pathology 54:7-19.

Latipudin, D. dan A. Mushawwir. 2011. Regulasi panas tubuh ayam ras petelur fase grower dan layer. J. Sains Peternakan Indonesia. 6:77-82.

Lawhead, J. B. and Baker, M. 2005. Introduction to Veterinary Science. Thomson and Learning. Australia.

Mahmmod, Y. S., Elbalkemy, F. A., Klaas, I. C., Elmekkawy, M. F., and A.M. Monazie. 2011. Clinical and haematological study on water buffaloes (Bubalus bubalis) and crossbread cattle naturally infected with Theileria annulata in Sharkia province, Egypt. Tick and Tick-borne Diseases. 54:1-4.

Mushawwir, A. Y.K. Yong, L. Adriani, E. Hernawan, and K.A. Kamil. 2010. The Fluctuation effect of atmospheric Ammonia (NH3) exposure and microclimate on hereford bulls hematochemical. J. of the Indon Tropical Anim Agric. 35:232-238.

Mushawwir, A., L. Adriani, and K.A. Kamil. 2011. Prediction models for olfactory Metabolic and Sows\% rnareticulocyt (rnart) by measurement of atmospheric ammonia exposure and microclimate level. J. of the Indon Tropical Anim Agric. 36:14-20.

Mushawwir, A. 2015. Biokimi Nutrisi. Widya Padjadjaran, Bandung Mushawwir, A, U. H. Tanuwiria, K.A. Kamil, L. Adriani, and R. Wiradimadja. 2017. Effects of Volatile Oil of Garlic on Feed Utilization, Blood Biochemistry and Performance of Heat-stressed Japanese Quail. Asian J. of Poultry Science. 11:83-89.

Mushawwir, A, U.H. Tanuwiria, Kurnia Kamil, L. Adriani, R. Wiradimadja, N.Suwarno. 2018. Evaluation of haematological responses and blood biochemical parameters of heat-stressed broilers with dietary supplementation of javanese ginger powder (Curcuma xanthorrhiza) and garlic extract (Allium sativum). International J. of Poultry Sci. 17:452458.

Mushawwir, A., N. Suwarno, A.A. Yulianti, dan R. Permana. 2019a. Dampak pemberian minyak atsiri bawang putih terhadap histologi illeum itik cihateup fase pertumbuhan yang dipelihara sacara ekstensif. J. Peternakan Sriwijaya. 8:35-44.

Mushawwir, A., N. Suwarno, dan A.A. Yulianti. 2019b. Profil malondial dehyde (MDA) dan kreatinin itik fase layer yang diberi minyak atsiri garlic dalam kondisi cekaman panas. J. Ilmu dan Industri Peternakan. 5:1-11.

Mushawwir, A., N. Suwarno, dan A.A. Yulianti. 2019c. Thermoregulasi domba ekor gemuk yang dipelihara pada ketinggian tempat (altitude) yang berbeda. J. Ilmu dan Industri Peternakan. 5:77-86.

Mushawwir, A., N. Suwarno, dan D. Latipudin. 2020a. Profil metabolik 
jalur glikogenolisis puyuh dalam kondisi stres panas dengan pemberian diallyl n-sulfida (dn-s) organic. J. Galung Tropika. 9:48-59.

Mushawwir, A., N. Suwarno, dan R. Permana. 2020b. Profil non-esterified fatty acids (NEFA) dan trigliserida ayam sentul pada sistem pemeliharaan berbeda. J. Ilmu dan Industri Peternakan. 6:14-24.

Mushawwir, A., A.A. Yulianti, N. Suwarno, dan R. Permana. 2020c. Profil metabolit plasma darah dan aktivitas kreatin kinase sapi perah berdasarkan fluktuasi mikroklimat lingkungan kandangnya. J. Veteriner. 21:24-30.

Mushawwir, A., A.A. Yulianti, dan N. Suwarno. 2020d. Histologi liver burung puyuh dengan pemberian minyak atsiri bawang putih. J. Ilmu dan Teknologi Peternakan. 8:1-7.

Mutaqin, B.K., D. S. Tasripin, L. Adriani, U. H.Tanuwiria. 2019. Effect of the addition of Ca-PUFA complexes to complete rations on fermentability and digestibility. Pakistan J. of Nutrition. 18:519-523.

Novia, Q., Y. Retnani, dan I.G. Permana. 2015. Kecernaan bahan kering dan bahan organik wafer daun kaliandra pada kambing peranaan etawah. Agros. 17:13-120.

Nuraeni, N. 2009. Pengaruh Pemberian Zat Besi Berlebih Terhadap Jumlah Neutrofil dan Limfosit Pada Kelinci. Fakultas Peternakan. Universitas Padjadjaran. Bandung.

Pangestu, E., T. Toharmat, dan U.H. Tanuwiria. 2003. Nilai nutrisi ransum berbasis limbah industri pertanian pada sapi perah laktasi. J. Indon. Trop. Anim. Agric. 28:166-171.

Phillips, D., Rezvani, K., and B.J. Bain. 2000. Exercise induced morbilization of the marginated granulocyte pool in the investigation of ethnic neutropenia. J. of clinical pathology. 53:481-483.

Roshetko, J. M., Lesueur, D., dan Sarrailh, J. 2001. Penanaman. Dalam: Produksi dan Pemanfaatan Kaliandra
(Calliandra calothyrsus) Pedoman

Lapang. Editor: Stewart, J., Mulawarman, J. M. Roshetko, M. H. Powell. Terjemahan:SN Kartikasari. Winrock International Institute for Agricultural Development.

Santosa, U., U.H. Tanuwiria, A. Yulianti, dan U. Suryadi. 2012. Pemanfaatan kromium organik limbah penyamakan kulit untuk mengurangi stres transportasi. J. Ilmu Ternak dan Veteriner. 17:132-141.

Sirait J., A. Tarigan, dan K. Simanihuruk. 2014. Produksi dan nilai nutrisi rumput gajah kerdil (Pennisetum purpureum cv. Mott) pada jarak berbeda di dua kabupaten di Sumatera Utara. Sei Putih (Indonesia): Loka Penelitian Kambing Potong.

Smith, J. B dan Mangkoewidjojo Soesanto.1998. Pemeliharaan, Pembiakan, dan Penggunaan Hewan Percobaan di Daerah Tropis. Penerbit Universitas Indonesia. Jakarta.

Susilawati, I., N.P. Indriani, L. Khairani, and U.H. Tanuwiria. 2019. Increase nutritional content and in vitro digestibility of forage legumes by adding molybdenum with foliar spray methods. Legume Research: An International J. 42: 35-42.

Syarifuddin, N. A. 2006. Nilai Gizi Rumput Gajah Sebelum dan Setelah Enzilase Pada Berbagai Umur Pemotongan. Produksi Ternak. Fakultas Pertanian UNLAM, Lampung.

Tangendjaja, B. and E. Wina. 2000. Tannins and ruminant production in Indonesia. In: Brooker, Tannins in Livestock and Human Nutrition. ACIAR Proceeding. 92:40-43.

Tanuwiria, U.H. 2004. Efek suplementasi Zn$\mathrm{Cu}$ proteinat dalam ransum terhadap fermentabilitas dan kecernaan in vitro. J. Ilmu Ternak. 4:7-12.

Tanuwiria, U.H. 2007a. Proteksi protein tepung ikan oleh berbagai sumber tannin dan pengaruhnya terhadap fermentabilitas dan kecernaannya (in vitro). J. Agroland. 14:56-60. 
Tanuwiria, U.H., 2007b. Efek suplementasi kompleks mineral-minyak dan mineral-organik dalam ransum terhadap kecernaan ransum, populasi mikroba rumen dan performa produksi domba jantan. Prosiding Seminar Nasional dan Kongres Asosiasi Ahli Nutrisi. AINI. 1:23-27.

Tanuwiria, U.H., A. Mushawwir, dan A.A. Yulianti. 2007. Potensi pakan serat dan daya dukungnya terhadap populasi ternak ruminansia di wilayah kabupaten Garut. Jurnal Ilmu Ternak. 7:11-16.

Tanuwiria, U.H., D. Tasrifin, dan A. Mushawwir. 2020. Respon gamma glutamil transpeptidase $(\gamma$-gt) dan kadar glukosa sapi perah pada ketinggian tempat (altitude) yang berbeda. J. Ilmu dan Industri Peternakan. 6:25-34.

Willyan, D., Kuswaryan, S., dan Tanuwiria, U. H. 2007. Efek substitusi konsentrat dengan daun kering kaliandra dalam ransum sapi perah terhadap kuantitas dan kualitas susu, bobot badan dan pendapatan peternak. Seminar Nasional Teknologi Peternakan dan Veteriner, Fakultas Peternakan, Universitas Padjadjaran, Bandung. 